ISSN 1392-3196 / e-ISSN 2335-8947

Zemdirbyste-Agriculture, vol. 108, No. 2 (2021), p. 153-158

DOI 10.13080/z-a.2021.108.020

\title{
Potential of lactic acid bacteria in biocontrol of Aspergillus niger, Penicillium chrysogenum and Fusarium graminearum in culture media and natural substrate
}

\author{
Gabriella KANIŽAI ŠARIĆ ${ }^{1}$, Irena RAPČAN ${ }^{1}$, Ivana POTOČNIK ${ }^{2}$, \\ Ankica SARAJLIĆ ${ }^{1}$, Ivana MAJIĆ ${ }^{1}$ \\ ${ }^{1}$ Josip Juraj Strossmayer University of Osijek, Faculty of Agrobiotechnical Sciences \\ Trg Svetog Trojstva 3, 31000 Osijek, Croatia \\ E-mail: gkanizai@fazos.hr \\ ${ }^{2}$ Institute of Pesticides and Environmental Protection \\ Banatska 31B, 11080 Belgrade, Serbia
}

\begin{abstract}
Adverse storage conditions impair the quality of stored grain, contribute to the growth and propagation of the fungi leading to an even greater deterioration of the grain quality. Antifungal biopreparations can help preserve grain quality. Lactic acid bacteria (LAB) and their metabolites with antifungal properties can potentially be used in storage conditions or for the decontamination of stored products. The aim of this study was to determine the antifungal activity of Lactobacillus casei, Lactobacillus brevis and Leuconostoc mesenteroides on the inhibition of mycelial growth of pathogenic fungi Aspergillus niger, Penicillium chrysogenum and Fusarium graminearum. The biocontrol potential of LAB against fungi was tested under laboratory conditions in culture media as an ideal substrate for fungal growth and wheat grains as a model of natural substrate. A liquid culture media (MRS broth) was inoculated with cells or cell-free supernatants (CFS) of each LAB species and the fungal spores. The fungal growth was evaluated by measuring the increase in mycelial biomass after 7, 14, 21 and 28 days of incubation. The second antifungal assay was performed on the wheat grain treated with LAB CFS and inoculated with fungal spores. Biopreparation containing cells or CFS of all LAB species significantly inhibited the fungal growth of $P$. chrysogenum (mean inhibition 69-75\% LAB cells and 80-81\% LAB CFS) and F. graminearum (mean inhibition 60-83\% LAB cells and 83-88\% LAB CFS) in the culture media. In the treatment with wheat grain, the CFS of all the tested LAB species significantly inhibited only the growth of $F$. graminearum (83-90\% mean inhibition). There is inconsistency in the efficiency of LAB preparations when comparing assays. The results indicate that media used in the experiment affect the activity or tolerance of the tested bacteria and fungi. L. casei, L. brevis and L. mesenteroides proved their antifungal properties in the culture media and natural substrate. F. graminearum was the most susceptible, and $A$. niger was the most tolerant to treatments with LAB cells and LAB CFS.

More research is needed to reveal the mode of action of the LAB against phytopathogenic fungi in different conditions for their application on stored grains.
\end{abstract}

Key words: Lactobacillus brevis, Lactobacillus casei, Leuconostoc mesenteroides, antifungal activity, wheat grain.

\section{Introduction}

The microbial population of stored grain is primarily dominated by fungi (Los et al., 2018). Fungal growth depends on the nutritional composition of grain and abiotic and biotic factors (Atanda et al., 2011). Further, biotic and microbial activity can cause undesirable effects on grain including discoloration, loss of dry matter and germination, which leads to reduced quality and represents a significant risk to the food chain (Magan, Aldred, 2007). Likewise, such conditions can contribute to growth and propagation of fungi. The most common contaminants of crops and stored grains are fungi belonging to orders Aspergillus, Penicilium and Fusarium (Atanda et al., 2011; Cosić et al., 2012; Fleurat-Lessard, 2017; Mannaa, Kim, 2017). These fungi are also mycotoxin producers, whose ingestion causes acute or chronic toxicosis in humans and animals. Postharvest treatment before and during storage is important in the prevention of such fungal spoilage and mycotoxin biosynthesis (Schmidt et al., 2018).

The main focus is on the prevention of fungal activity in the chain from farm to table; however, if contamination occurs during storage, decontamination or

Please use the following format when citing the article:

Kanižai Šarić G., Rapčan I., Potočnik I., Sarajlić A., Majić I. 2021. Potential of lactic acid bacteria in biocontrol of Aspergillus niger, Penicillium chrysogenum and Fusarium graminearum in culture media and natural substrate. Zemdirbyste-Agriculture, 108 (2): 153-158. DOI 10.13080/z-a.2021.108.020 
detoxification procedures can be used (Fleurat-Lessard, 2017). Decontamination includes physical, biological and chemical treatments. Consumer requirements are focused on foods with minimum or no chemical residues; therefore, physical and biological (microbiological) treatments are the main tools in post-harvest control of microbial spoilage in cereals (Liška et al., 2017; Schmidt et al., 2018). Microbiological treatments must satisfy certain criteria: in general, they must be efficient, harmless to humans and animals, and the principles of sustainable agriculture and consumer demands insist on environmental acceptability. Biopreparations meet these criteria. The use of biopreparations in combination with other protection measures would meet the requirements for the production of health-safe agricultural products and food in general (Martinez, 2015). Biopreparations in the control of phytopathogenic fungi can be based upon antagonistic microorganisms or their metabolites (Gomah, Zohri, 2014).

Lactic acid bacteria (LAB) and their metabolites could act as bioagents and replace traditionally used chemical products in pest management (Schnürer, Magnusson, 2005). In fermented food, LAB produce organic acids, ethanol, hydrogen peroxide and bacteriocin with antimicrobial properties (De Vuyst, Leroy, 2007). The antifungal efficacy of LAB was confirmed in a series of studies (Magnusson et al., 2003; Muñoz et al., 2010; Schillinger, Villarreal, 2010; Matei et al., 2014).

An antagonistic LAB strain against Aspergillus ochraceus was identified in an assay on agar medium and recommended to be used as a biocontrol agent (Matei et al., 2014). Lactobacillus fermentum and L. rhamnosus showed fungal growth inhibition of Aspergillus nomius on plates using an overlay technique (Muñoz et al., 2010). Antifungal properties of LAB against Penicillium nordicum on agar plates were also determined (Schillinger, Villarreal, 2010). Some of LAB isolates are able to inhibit mycotoxin synthesis in vitro and in vivo (Oluwafemi et al., 2010; Franco et al., 2011; Zou et al., 2012). LAB produce a diversity of antimicrobial compounds affecting the populations of bacterial and fungal phytopathogens of crop plants; therefore, it is recommended as a probiotic in different agricultural ecosystems (Oliveira et al., 2014; Fleurat-Lessard, 2017; Lamont et al., 2017). The use of $\mathrm{LAB}$ and their metabolites as a potential measure in prevention of grain deterioration or decontamination in storage conditions should also be considered.

Considering the growing interest in the use of natural and with low ecological impact antimicrobial compounds in agricultural production, storage and decontamination, the experiment to test the antifungal activity of LAB was conducted. The objectives of the study were to determine the effect of Lactobacillus brevis, L. casei and Leuconostoc mesenteroides and their metabolic products in cell-free supernatants on the growth of frequent storage fungal contaminants Penicillium chrysogenum, Aspergillus niger and Fusarium graminearum in culture media and wheat grain as a natural substrate.

\section{Materials and methods}

Microbial isolates and growth media. Lactic acid bacteria (LAB) used in the experiment were: Lactobacillus casei, Lactobacillus brevis and Leuconostoc mesenteroides, previously isolated from diary and fermented products at the Faculty of Agrobiotehnical Sciences, J. J. Strossmayer University of Osijek,
Croatia. LAB isolates were cultivated on MRS (De Man, Rogosa and Sharpe) broth $48 \mathrm{~h}$ at $37^{\circ} \mathrm{C}$ temperature. For experimental purposes, LAB cell-free supernatants (CFS) were prepared by centrifuge Centric 150 (Domel d.o.o., Slovenia) at 10,000 rpm for $15 \mathrm{~min}$ and sterilized by filter (Sartorius GmbH, Germany) through $0.2 \mu \mathrm{m}$ pore size.

Fungal isolates of Penicillium chrysogenum and Aspergillus niger previously isolated at the Faculty of Agrobiotechnical Sciences, J. J. Strossmayer University of Osijek, Croatia and Fusarium graminearum Schwabe 110250 (The Westerdijk Fungal Biodiversity Institute, the Netherlands) were used in the experiment. The fungal isolates were cultivated on potato dextrose agar slants (Biolife $\mathrm{Srl}$, Italy) for 7 days at $25^{\circ} \mathrm{C}$ temperature. The spores were dislodged from the hyphae with a sterile spreader after flooding the culture media with sterile saline solution. The number of spores was determined using the hemocytometer (Feine-Optik, Germany) to a concentration of $10^{5}$ spores $\mathrm{ml}^{-1}$.

Antifungal assay in nutrient medium. The effect of LAB isolates and LAB CFS, separately, on the fungal biomass production in liquid medium was determined by double inoculation in MRS broth. LAB cells were equilibrated according to Grant Instruments ${ }^{\mathrm{TM}}$ Liquid McFarland standards (Fisher Scientific Ltd., UK) to $3 \times$ $10^{9} \mathrm{LAB}$ cells $\mathrm{ml}^{-1}$. MRS broth $(10 \mathrm{ml})$ was inoculated with $200 \mu \mathrm{l}$ of LAB cells or LAB CFS and $200 \mu \mathrm{l}$ of tested fungal spores. The incubation temperature was $30^{\circ} \mathrm{C}$. The fungal growth was determined 7, 14, 21 and 28 days post treatment by extracting fungal biomass on Whatman No. 1 filter paper, which was dried to a constant mass at $50^{\circ} \mathrm{C}$ temperature for $2 \mathrm{~h}$.

Antifungal assay on wheat grain as a model of natural substrate. Organically cultivated wheat grains $(10 \mathrm{~g})$ were placed in a Petri dish and sterilized by pressurized water vapor. Compared to the in vitro antifungal assay, where both LAB and LAB CFS were tested, the grains were treated only with LAB CFS according to Deepthi et al. (2016). The fungal isolates $(100 \mu \mathrm{l})$ were centrally added to the Petri dish containing wheat grains. The fungal growth in two diameters at right angles to each other was evaluated daily until the colony reached the edge of the plate. The mean diameter of each dish was calculated. Fungal growth and time of incubation were used to calculate growth rates. The Petri dishes were incubated in three replicates at $30 \pm 0.2^{\circ} \mathrm{C}$ temperature. The fungal growth and time of incubation were used to calculate growth rates. In the control treatments of both bioassays, sterile distilled water was used instead of LAB. All tests were conducted under laboratory conditions in three replications and repeated twice during 2017 and 2018.

Statistical analysis. The results were statistically analysed by Statistica, version 13.5 (TIBCO Software Inc.). All variables were analysed by Student's $t$-test $(P<0.05)$ to test the effects of LAB and compare the differences of fungal growth between the fungal isolates.

\section{Results and discussion}

Inhibition of Penicillium chrysogenum growth by Lactobacillus brevis in culture media ranged from $50 \%$ to $79 \%$, L. casei inhibited growth from $37 \%$ to $76 \%$ and Leuconostoc mesenteroides reduced growth to $69 \%$ (Figure 1). LAB metabolic products in CFS were more effective, where $L$. brevis and $L$. casei inhibited growth 
from $66 \%$ to $85 \%$ and L. mesenteroides - from $33 \%$ to $75 \%$ (Figure 2). Statistical significance was observed between the tested mentioned LAB and the control from 14 to 28 days of incubation $(P<0.01)$.

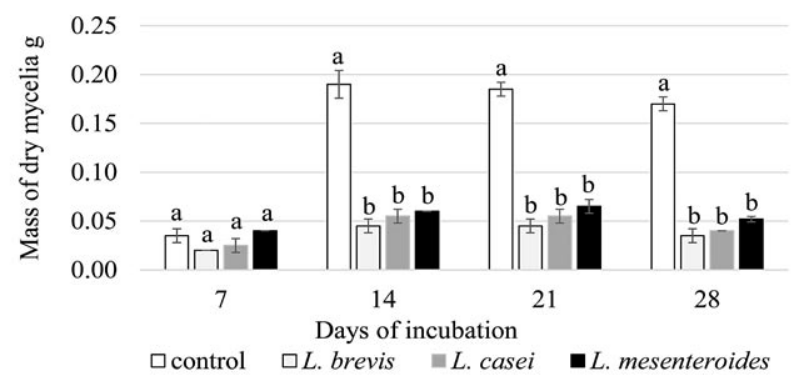

Note. Different letters in each column group indicate significant differences $(P<0.05$; Student's $t$-test $)$.

Figure 1. Penicillium chrysogenum biomass of dry mycelia affected by lactic acid bacteria (LAB) in culture media

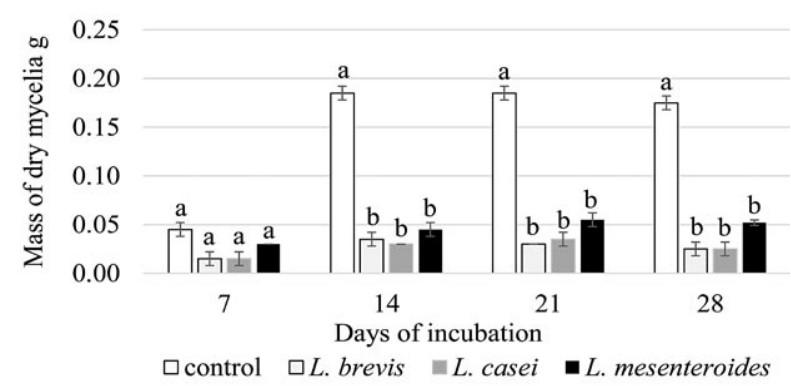

Explanation under Figure 1

Figure 2. Penicillium chrysogenum biomass of dry mycelia affected by lactic acid bacteria (LAB) cell-free supernatants (CFS) in culture media

LAB antifungal inhibition of the Penicillium spp. has been reported in other studies. Magnusson et al. (2003) have documented that Pediococcus pentosaceus inhibited the growth of Penicillium commune, and none of the isolates was successful in inhibiting Penicillium roqueforti in in vitro conditions.

Results of our experiment showed that Fusarium graminearum inhibition by $L$. brevis in culture media ranged from $50 \%$ to $88 \%, L$. casei inhibited growth from $70 \%$ to $82 \%$ and L. mesenteroides - from $60 \%$ to $79 \%$ (Figure 3). Antifungal products in the CFS were more effective, where inhibition was determined by L. brevis from $80 \%$ to $90 \%$, by $L$. casei - from $80 \%$ to $92 \%$ and L. mesenteroides - from $70 \%$ to $84 \%$ (Figure 4). A statistically significant difference of the tested LAB was observed from 7 to 28 days and LAB CFS - from 14 to 28 days of incubation compared to control $(P<0.01)$. Similar to the study of Magnusson et al. (2003), a strong inhibition of the growth of Fusarium sporotrichoides by Pediococcus pentosaceus, Lactobacillus plantarum, L. coryniformis, L. acidophilus, L. salivarius, L. sakei and Pediococcus parvulus was determined using a dual culture media overlay agar plates. Juodeikiene et al. (2018) found that supernatants of L. sakei, Pediococcus acidilactici, $P$. pentosaceus KTU05-8, P. pentosaceus KTU05-9 and $P$. pentosaceus KTU05-10 are very good inhibitors against in vitro mycelial growth and sporulation of Fusarium culmorum and F. poae. Treatments with the investigated strains resulted in the reduction of zearalenone (ZEA), deoxynivalenol (DON), T-2 and HT2 toxins concentration in malting grains by $23,34,58$ and $73 \%$, respectively. In a study by Franco et al. (2011) commercial culture media Lyofast LPRA (L. rhamnosus and $L$. plantarum) showed the greatest inhibition effects against $F$. graminearum IAPAR 2218 using agar diffusion method, also all LAB isolated strains and commercial cultures showed potential for DON removal in liquid media.

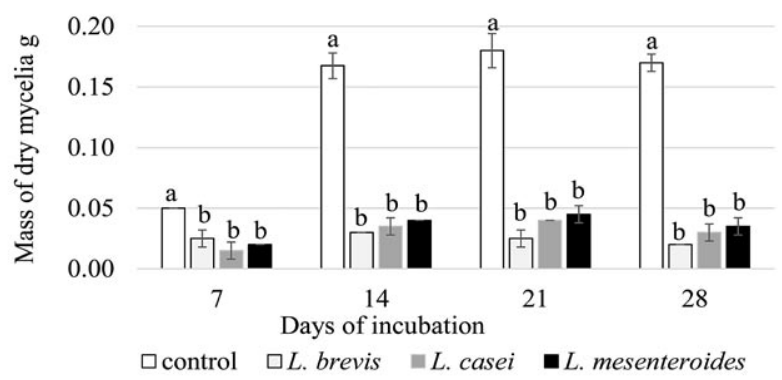

Explanation under Figure 1

Figure 3. Fusarium graminearum biomass of dry mycelia affected by lactic acid bacteria (LAB) in culture media

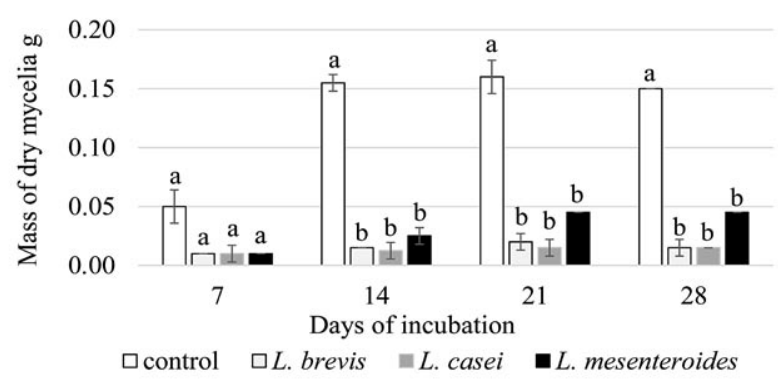

Explanation under Figure 1

Figure 4. Fusarium graminearum biomass of dry mycelia affected by lactic acid bacteria (LAB) cell-free supernatants (CFS) in culture media

Lactobacillus brevis and L. casei showed statistical significance in Aspergillus inhibition that decreased with incubation time (Figure 5). CFS Leuconostoc mesenteroides showed statistical significance $(P<0.01)$ in the Aspergillus niger inhibition ranging from $31 \%$ to $42 \%$ (Figure 6 ). The investigated strains of LAB and CFS LAB did not show efficiency determined with previously tested fungi in culture media. In the study of Magnusson et al. (2003), strong growth inhibition of Aspergillus fumigatus by the L. plantarum, $L$. coryniformis and $P$. pentosaceus was found. Also, in the study of Ben Taheur et al. (2019), Lactoballus kefiri in agar medium showed the highest fungal inhibition against Aspergillus flavus and A. carbonarius. The decrease of fungal biomass was recorded in the study of Kim (2005) in liquid MRS broth inoculated with LAB and A. fumigatus: was recorded $75 \%$ fungal biomass inhibition in Lactobacillus curvatus KC-116, 45\% in Lactococcus lactis subsp. lactis KC-304, 92\% in L. casei $\mathrm{KC}-324,95 \%$ in Lactobacillus pentosus KC-817, and $40 \%$ in L. sakei KC-1004, respectively.

The action path of LAB is dependent on various factors: the characteristics of each species or strain of $\mathrm{LAB}$, the properties of the fungi to be inhibit and their biotic interactions. Some species of LAB show specific inhibition patterns, and antifungal compounds identified 


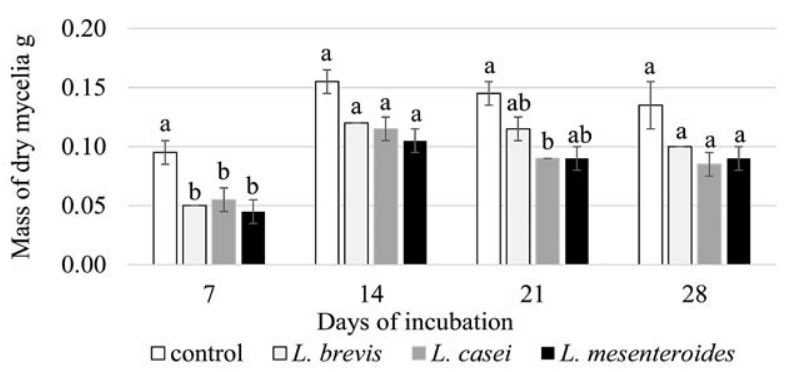

Explanation under Figure 1

Figure 5. Aspergillus niger biomass of dry mycelia affected by lactic acid bacteria (LAB) in culture media

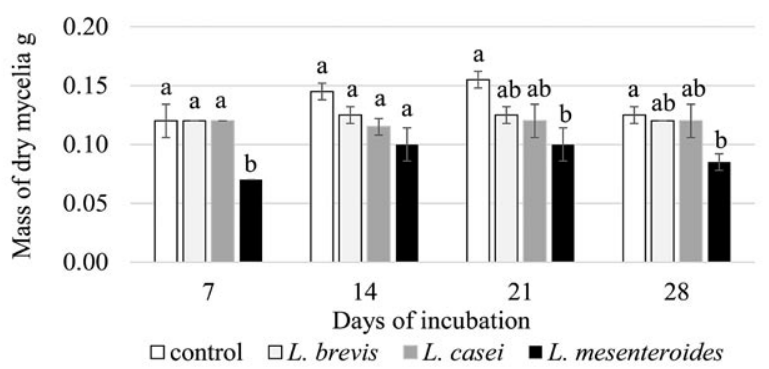

Explanation under Figure 1

Figure 6. Aspergillus niger biomass of dry mycelia affected by lactic acid bacteria (LAB) cell-free supernatants (CFS) in culture media from LAB CFS are cyclic dipeptides, phenyllactic acid, lactic acid, proteinaceous and some unknown substances (Magnusson, Schnürer, 2001). Yang and Clausen (2005) showed that supernatants of Lactobacillus casei subsp. rhamnosus and L. acidophilus retained antifungal properties in the absence of lactic and phenyllactic acids. In the same study, the investigated LAB CFS produced at least four unknown substances with antifungal properties against Trichoderma viride ATCC 20476, A. niger 2.242, P. chrysogenum $\mathrm{PH} 02$ and Aureobasidium pullulans MDX-18. These antifungal compounds were heat resistant (to $121^{\circ} \mathrm{C}$ ) and maintained activity after neutralization. Magnusson et al. (2003) have come to a similar conclusion in a study, where the degree of fungal inhibition is not only associated with the production of lactic or acetic acids, but also some antifungal cyclic dipeptides were identified.

In real systems, more complex interactions between the substrate and the antifungal agent prevailed and applied treatments were less effective compared to the first experiment. As well as in an experiment on culture media, none of the LAB species tested statistically inhibited the mycelial growth of $A$. niger on wheat grains (Table).

There was detected a prolongation of incubation time from 4 to 7 days in the treatments when compared to the control, suggesting an antifungal activity but not statistically significant inhibition. There was also no significant inhibition of $P$. chrysogenum on wheat grains, although a decrease in growth was observed in the range of $76-82 \%$, while the incubation time was prolonged

Table. Mean values of growth rates of the fungal isolates on wheat grains treated with lactic acid bacteria (LAB) cellfree supernatants (CFS)

\begin{tabular}{lcccccc}
\hline \multicolumn{1}{c}{ Tested fungi } & \multicolumn{2}{c}{ Aspergillus niger } & \multicolumn{2}{c}{ Penicillium chrysogenum } & Fusarium graminearum \\
\cline { 2 - 7 } \multicolumn{1}{c}{ Treatment, } & \multicolumn{7}{c}{ Growth rate on wheat grains } \\
\cline { 2 - 7 } & $\mathrm{mm} \mathrm{day}^{-1}$ & $P$ & $\mathrm{~mm} \mathrm{day}^{-1}$ & $P$ & mm day $^{-1}$ & $P$ \\
\hline Control & 5.4 & 5.0 & & 7.2 & $<0.01^{* *}$ \\
Lactobacillus brevis & 3.5 & $0.686 \mathrm{~ns}$ & 1.5 & $0.963 \mathrm{~ns}$ & 0.4 & $<0.01^{* *}$ \\
Lactobacillus casei & 3.4 & $0.786 \mathrm{~ns}$ & 1.3 & $0.594 \mathrm{~ns}$ & 0.5 & $<0.01^{* *}$ \\
\hline Leuconostoc mesenteroides & 2.8 & $0.919 \mathrm{~ns}$ & 2.4 & $0.679 \mathrm{~ns}$ & 0.5 & \\
\hline
\end{tabular}

** - growth rate significantly lower than control $(P<0.01)$; ns - not significant

from 14 to 16 days compared to the control. A similar influence of the complex interactions between LAB and wheat grains was observed by Suproniene et al. (2015). Antifungal properties of $L$. sakei KTU05-6, Pediococcus acidilactici KTU05-7 and P. pentosaceus KTU05-8, KTU05-9 and KTU05-10 on untreated wheat grains were tested. Results showed that the occurrence of Fusarium spp. on wheat grains treated with LAB depended on incubation temperature and applied volume of LAB. Strain P. pentosaceus and mixtures of $P$. acidilactici + P. acidilactici and L. sakei + P. acidilactici + P.pentosaceus significantly reduced growth of Fusarium spp., Bipolaris sorokiniana and Alternaria spp. on wheat grains. Other effects on seed germination and seedling pathogens in laboratory and field trials were insignificant. Researchers concluded that in field conditions LAB failed to produce inhibitory substances for the control of plant pathogens in the complex soil environment.

Promising results of this experiment include the antifungal activity of $L$. casei, L. brevis and L. mesenteroides with $83-90 \%$ mean inhibition of F. graminearum mycelial growth $(P<0.01)$. Similar results were obtained in the study of Abdel-Aziz et al. (2014), where LAB was evaluated against Fusarium oxysporum. Tomato seeds were pre-treated with Lactobacillus sp., L. acidophilus and L. plantarum and showed an increase in the root, shoot and seedling lengths as well as vigour index and plant weight. In the study of Varsha et al. (2015), 2,4 DTBP (2,4-di-tert-butyl phenol) obtained from the CFS of Lactococcus showed fungicidal activity on wheat grains, where fungal mycelial growth of $F$. oxysporum, $A$. niger and $P$. chrysogenum was completely inhibited. Similar studies of Gupta and Srivastava (2014) have shown that the treatment of wheat grains with peptides of L. plantarum LR14 not only prevented the seed borne fungal growth, but the antifungal effect was also retained after 2.5 years of storage under laboratory conditions.

It is evident that the LAB and their metabolites have antifungal activity in culture media and natural substrate and are potential candidates for use in storage conditions. Future research should focus on biotechnical improvement in a real environment. Possible solutions include their application in powder form to prevent increases in grain moisture in storage conditions. Further research also is needed to determine the active antifungal substances that metabolize investigated LAB, to clarify 
the complexity of interactions in in vivo systems, to examine the effectiveness of treatments on non-sterile grains and to identify interactions between the natural microflora of grains and LAB antifungal substances. Further, it would be desirable to determine the effect of LAB on the biosynthesis of mycotoxins produced by the tested fungi in agricultural systems.

\section{Conclusions}

1. The results of this study confirmed the significant antifungal activity of all lactic acid bacteria (LAB) species and their metabolites in the supernatants.

2. Lactobacillus brevis and L. casei induced significant inhibition of mycelial growth of Penicillium chrysogenum and Fusarium graminearum in the culture media from $7^{\text {th }}$ to $28^{\text {th }}$ day of incubation. The efficacy of their cell-free supernatants (CFS) was higher compared to the treatments with LAB cells, whereas fungal growth inhibition of $P$. chrysogenum ranged $81-86 \%$ and that of F. graminearum - 87-92\%, respectively.

3. Leuconostoc mesenteroides and their CFS were significantly effective in inhibition of all three fungal species and their mycelial growth in the culture media. The best antifungal activity for Aspergillus niger was achieved by this LAB species - mean inhibition of fungal growth was $31-50 \%$. The inhibition of fungal growth of $P$. chrysogenum ranged $70-76 \%$ and that of $F$. graminearum - 70-92\%, respectively.

4. A. niger was the most tolerant phytopathogenic fungi in the culture media and natural substrate.

5. On wheat grains as a natural substrate, the LAB treatments were less effective; however, satisfactory results were obtained for $F$. graminearum with $83-90 \%$ mean inhibition of mycelial growth.

Received 02102020

Accepted 02022021

\section{References}

Abdel-Aziz S. M., Moustafa Y. A. Hamed H. A. 2014 Lactic acid bacteria in the green biocontrol against some phytopathogenic fungi: treatment of tomato seeds. Journal of Basic and Applied Scientific Research, 4 (12): 1-9.

Atanda S. A., Pessu P. O., Agoda S., Isong I. U., Adekalu O. A., Echendu M. A., Falade T. C. 2011. Fungi and mycotoxins in stored foods. African Journal of Microbiology Research, 5 (25): 4373-4382. https://doi.org/10.5897/AJMR11.487

Ben Taheur F., Mansour C., Kouidhi B., Chaieb K. 2019. Use of lactic acid bacteria for the inhibition of Aspergillus flavus and Aspergillus carbonarius growth and mycotoxin production. Toxicon. 166: 15-23. https://doi.org/10.1016/j.toxicon.2019.05.004

Ćosić J., Vrandečić K., Jurković D., Abramović B., Jajić I., Jakšić S. 2012. Mycopopulation of cereals in Croatia. Alexa E. et al. (eds). Occurrence of fungi and mycotoxins in cereals and medicinal plants from Romania-SerbiaCroatia area. EUROBIT, p. 88-106.

De Vuyst L., Leroy F. 2007. Bacteriocins from lactic acid bacteria: production, purification, and food applications. Journal of Molecular Microbiology and Biotechnology, 13 (4): 194-199. https://doi.org/10.1159/000104752

Deepthi B. V., Poornachandra Rao K., Chennapa G., Naik M. K., Chandrashekara K. T., Sreenivasa M. Y. 2016. Antifungal attributes of Lactobacillus plantarum MYS6 against fumonisin producing Fusarium proliferatum associated with poultry feeds. PLoS ONE. 11 (6): e0155122. https://doi.org/10.1371/journal.pone.0155122
Fleurat-Lessard F. 2017. Integrated management of the risks of stored grain spoilage by seedborne fungi and contamination by storage mould mycotoxins - an update. Journal of Stored Products Research. 71: 22-40. https://doi.org/10.1016/j.jspr.2016.10.002

Franco T. S., Garcia S., Hirooka E. Y., Ono Y. S., dos Santos J. S. 2011. Lactic acid bacteria in the inhibition of Fusarium graminearum and deoxynivalenol detoxification. Journal of Applied Microbiology, 111 (3): 739-748. https://doi.org/10.1111/j.1365-2672.2011.05074.x

Gomah N. H., Zohri A. N. 2014. Inhibition of fungal growth and Fusarium toxins by selected cultures of lactic acid bacteria. Journal of Microbial and Biochemical Technology, S7. https://doi.org/10.4172/1948-5948.S7-001

Gupta R., Srivastava S. 2014. Antifungal effect of antimicrobial peptides (AMPs LR14) derived from Lactobacillus plantarum strain LR/14 and their applications in prevention of grain spoilage. Food Microbiology, 42: 1-7. https://doi.org/10.1016/j.fm.2014.02.005

Juodeikiene G., Bartkiene E., Cernauskas D., Cizeikiene D., Zadeike D., Lele V., Bartkevics V. 2018. Antifungal activity of lactic acid bacteria and their application for Fusarium mycotoxin reduction in malting wheat grains. LWT - Food Science and Technology, 89: 307-314. https://doi.org/10.1016/j.lwt.2017.10.061

Kim J.-D. 2005. Antifungal activity of lactic acid bacteria isolated from Kimchi against Aspergillus fumigatus. Mycobiology, 33 (4): 210-214. https://doi.org/10.4489/MYCO.2005.33.4.210

Lamont J. R., Wilkins O., Bywater-Ekegärd M., Smith D. L. 2017. From yogurt to yield: potential applications of lactic acid bacteria in plant production. Soil Biology and Biochemistry, 111: 1-9. https://doi.org/10.1016/j.soilbio.2017.03.015

Liška A. Korunić Z., Rozman V., Halamić J., Galović I., Lucić P., Baličević R. 2017. Efficacy of nine Croatian inert dusts against rice weevil Sitophilus oryzae L. (Coleoptera: Curculionidae) on wheat. Emirates Journal of Food and Agriculture, 29 (7): 485-494. https://doi.org/10.9755/ejfa.2016-09-1302

Los A., Ziuzina D., Bourke P. 2018. Current and future technologies for microbiological decontamination of cereal grains. Journal of Food Science. 83 (6): 1484-1493. https://doi.org/10.1111/1750-3841.14181

Magan N., Aldred D. 2007. Post-harvest control strategies: minimizing mycotoxins in the food chain. International Journal of Food Microbiologv. 119 (1-2): 131-139. https://doi.org/10.1016/j.ijfoodmicro.2007.07.034

Magnusson J., Schnürer J. 2001. Lactobacillus coryniformis subsp. coryniformis strain Si3 produces a broad-spectrum proteinaceous antifungal compound. Applied and Environmental Microbiology, 67 (1): 1-5. https://doi.org/10.1128/AEM.67.1.1-5.2001

Magnusson J., Ström K., Roos S., Sjögren J., Schnürer J. 2003. Broad and complex antifungal activity among environmental isolates of lactic acid bacteria. FEMS Microbiology Letters, 219 (1): 129-135. https://doi.org/10.1016/S0378-1097(02)01207-7

Mannaa M., Kim K. D. 2017. Influence of temperature and water activity on deleterious fungi and mycotoxin production during grain storage. Mycobiology, 45 (4): 240-254. https://doi.org/10.5941/MYCO.2017.45.4.240

Martinez M. M. 2015. Microbial bioproducts for agriculture. Acta Horticulturae. 1076: 71-76. https://doi.org/10.17660/ActaHortic.2015.1076.7

Matei G. M., Matei A., Matei S. 2014. Screening of lactic acid bacterial and fungal strains for their efficiency in in biocontrol of mycotoxigenic contaminants of food. Research Journal of Agricultural Science. 46 (2): 182-190. https://doi.org/10.13140/RG.2.2.25181.03042

Muñoz R., Arena M. E., Silva J., González S. N. 2010. Inhibition of mycotoxin-producing Aspergillus nomius vsc 23 by lactic acid bacteria and Saccharomyces cerevisiae. Brazilian Journal of Microbiology, 41 (4): 1019-1026. https://doi.org/10.1590/S1517-83822010000400021 
Oliveira P. M., Zannini E., Arendt E. K. 2014. Cereal fungal infection, mycotoxins, and lactic acid bacteria mediated bioprotection: from crop farming to cereal products. Food Microbiology. 37: 78-95. https://doi.org/10.1016/j.fm.2013.06.003

Oluwafemi F., Kumar M., Bandyopadhyay R., Ogunbanwo T., Ayanwande K. B. 2010. Bio-detoxification of aflatoxin B in artificially contaminated maize grains using lactic acid bacteria. Toxin Reviews. 29 (3-4): 115-122. https://doi.org/10.3109/15569543.2010.512556

Schillinger U., Villarreal J. V. 2010. Inhibition of Penicillium nordicum in MRS medium by lactic acid bacteria isolated from foods. Food Control. 21 (2): 107-111. https://doi.org/10.1016/j.foodcont.2008.11.010

Schmidt M., Zannini E., Arendt E. K. 2018. Recent advances in physical post-harvest treatments for shelf-life extension of cereal crops. Foods. 7 (4): 45. https://doi.org/10.3390/foods7040045

Schnürer J., Magnusson J. 2005. Antifungal lactic acid bacteria as biopreservatives. Trends in Food Science and Technology, 16 (1-3): 70-78.

https://doi.org/10.1016/j.tifs.2004.02.014
Suproniene S., Semaskiene R., Juodeikiene G., Mankeviciene A., Cizeikiene D., Vidmantiene D., Basinskiene L., Sakalauskas S. 2015. Seed treatment with lactic acid bacteria against seedborne pathogens of spring wheat. Biocontrol Science and Technology. 25 (2): 144-154. https://doi.org/10.1080/09583157.2014.964661

Varsha K. K., Devendra L., Shilpa G., Priya S., Pandey A., Nampoothiri K. M. 2015. 2,4-Di-tert-butyl phenol as the antifungal, antioxidant bioactive purified from a newly isolated Lactococcus sp. International Journal of Food Microbiology. 211: 44-50. https://doi.org/10.1016/j.ijfoodmicro.2015.06.025

Yang V. W., Clausen C. A. 2005. Determining the suitability of Lactobacilli antifungal metabolites for inhibiting mould growth. World Journal of Microbiology and Biotechnology, 21: 977-981. https://doi.org/10.1007/s11274-004-7552-8

Zou Z.-Y., He Z.-F., Li H.-J., Han P- F., Meng X., Zhang Y., Zhou F., Ouyang K.-P., Chen X.-Y., Tang J. 2012. In vitro removal of deoxynivalenol and T-2 toxin by lactic acid bacteria. Food Science and Biotechnology, 21: 1677-1683. https://doi.org/10.1007/s10068-012-0223-x

\title{
Pieno rūgšties bakterijų potencialas Aspergillus niger, Penicillium chrysogenum ir Fusarium graminearum biokontrolei mitybinèje terpèje ir natūraliame substrate
}

\author{
G. Kanižai Šarić1 ${ }^{1}$ I. Rapčan ${ }^{1}$, I. Potočnik ${ }^{2}$, A. Sarajlić ${ }^{1}$, I. Majić ${ }^{1}$ \\ ${ }^{1}$ Osijeko Josip Juraj Strossmayer universiteto Agrobiotechnikos mokslų fakultetas, Kroatija \\ ${ }^{2}$ Pesticidų ir aplinkos apsaugos institutas, Serbija
}

\begin{abstract}
Santrauka
Nepalankios sandėliavimo sąlygos blogina sandèliuojamų grūdų kokybę ir skatina grybų augimą bei dauginimąsi. Grūdų kokybę gali padèti išsaugoti priešgrybiniai biopreparatai. Sandèliavimo metu arba siekiant nukenksminti sandèliuojamus produktus potencialiai gali būti naudojami pieno rūgšties bakterijos (PRB) ir priešgrybinių savybiu turintys ju metabolitai. Tyrimo tikslas - nustatyti Lactobacillus casei, Lactobacillus brevis ir Leuconostoc mesenteroides priešgrybini poveiki patogeninių grybų Aspergillus niger, Penicillium chrysogenum ir Fusarium graminearum grybienos augimo slopinimui. PRB biokontrolès priešgrybinis potencialas buvo tirtas laboratorinemis sąlygomis mitybinèse terpėse, kurios yra idealūs grybų augimo substratai, ir kviečių grūduose, tyrimo metu naudotų kaip natūralus substratas. Skysta terpè (SKT/MRS sultinys) buvo inokuliuota visų rūšių PRB arba PRB supernatantais ir grybų sporomis. Grybų augimas buvo įvertintas matuojant grybienos biomasès padidèjimą po inkubacijos praejus 7, 14, 21 ir 28 dienoms. Antras eksperimentas buvo atliktas su kviečių grūdais, apdorotais PRB supernatantais ir užkrèstais grybų sporomis. Biopreparatas, kuriame yra visų rūšių PRB arba jų supernatantų, reikšmingai slopino grybų augimą $P$. chrysogenum (slopino vidutiniškai $69-75 \%$ PRB ir $80-81 \%$ PRB supernatantų) ir F. graminearum (slopino vidutiniškai 60-83 \% PRB ir 83-88 \% PRB supernatantų) mitybinèse terpėse. Eksperimente su kviečių grūdais visų tirtų rūšių PRB supernatantai reikšmingai (vidutiniškai 83-90 \%) slopino tik $F$. graminearum augimą.

Lyginant eksperimentų rezultatus buvo pastebėtas PRB preparatų efektyvumo nenuoseklumas. Rezultatai rodo, kad per eksperimentą naudotos terpès darè itaką tirtų bakterijų ir grybų aktyvumui bei tolerancijai. L. casei, L. brevis ir L. mesenteroides priešgrybinès savybès buvo nustatytos mitybinèje terpèje ir natūraliame substrate. F. graminearum buvo jautriausias, o A. niger tolerantiškiausias apdorojimui PRB ir PRB supernatantais.

Siekiant PRB panaudoti sandèliuojant grūdus, reikia atlikti daugiau tyrimų, kurie atskleistų jų poveiki fitopatogeniniams grybams skirtingomis sąlygomis.
\end{abstract}

Reikšminiai žodžiai: Lactobacillus brevis, Lactobacillus casei, Leuconostoc mesenteroides, kviečių grūdai, priešgrybinis aktyvumas. 